\title{
Performance and Emission Analysis of Pongamia and Jatropha Biodiesels in a C.I. Engine
}

\author{
M. Manasa*, Shreekantgouda, Nagaraj Bake and Devanand Maski \\ College of Agricultural Engineering, UAS, Raichur, Karnataka, India \\ *Corresponding author
}

\section{A B S T R A C T}

Keywords

Biodiesel,

Pongamia, Jatropha,

Engine performance

Article Info

Accepted:

15 September 2018

Available Online:

10 October 2018

Biodiesels of vegetable oils are becoming increasingly popular because of their low environmental impact and potential as a green alternative fuel for diesel engine and they would not require significant modification of existing engine hardware. Methyl ester of Pongamia (PB) and Jatropha (JB) were derived through transesterification process. Experimental investigations have been carried out to examine performance and emissions of different blends (1:1, 2:1, and 1:2 by volume) of PB and JB in comparison to diesel. Results showed that brake specific fuel consumption for biodiesel and its blends was higher than that of diesel because of lower calorific value. Jatropha biodiesel had highest brake specific fuel consumption among all the test samples. $\mathrm{CO}_{2}$ emission produced by the $\mathrm{PB}$ and JB and their 3 blends were not significantly different than diesel fuel at all the levels of engine loadings. $\mathrm{NO}_{2}$ emission produced by the $\mathrm{PB}$ and $\mathrm{JB}$ and their 3 blends were slightly less than diesel fuel. $\mathrm{CO}$ emission of PB and JB and their 3 blends slightly higher than diesel fuel.

\section{Introduction}

Fuels derived from renewable biological resources for use in diesel engines are known as biodiesel. Biodiesel is environmentally friendly liquid fuel similar to petrol-diesel in combustion properties. Increasing environmental concern, diminishing petroleum reserves and agriculture based economy of our country are the driving forces to promote biodiesel as an alternate fuel. Biodiesel derived from vegetable oil and animal fats is being used in US and Europe to reduce air pollution, to reduce dependence on fossil fuel. In USA and Europe, their surplus edible oils like soybean oil, sunflower oil and rapeseed oil are being used as feed stock for the production of biodiesel. Since India is net importer of vegetable oils, edible oils cannot be used for production of biodiesel. India has the potential to be a world leading producer of biodiesel, as biodiesel can be harvested and sourced from non-edible oils like Jatropha curcus and Pongamia pinnata, neem (Azadirachta indica), mahua, castor, linseed, kusum (Schlechera trijuga), etc. Some of these oils produced even now are not being properly utilized. Out of these plants, India is focusing on Jatropha curcas and Pongamia pinnata, which can grow in arid and wastelands. Jatropha and pongamia seeds contain approximately $30-40 \%$ of oil content. 
India has about80-100 million hectares of waste land, which can be used for Jatropha and Pongamia plantation. India is one of the largest producers of neem oil and it is one of the untapped sources in India (Barnwal and Sharma, 2005; Agarwal et al., 2007). Implementation of biodiesel in India will lead to many advantages like green cover to wasteland, support to agriculture and rural economy and reduction in dependence on imported crude oil and reduction in air pollution.

\section{Tranesterification}

The formation of methyl esters by transesterification of vegetable oil requires raw oil, $15 \%$ of methanol and $5 \%$ of sodium hydroxide on mass basis. However, transesterification is an equilibrium reaction in which excess alcohol is required to drive the reaction very close to completion. The vegetable oil was chemically reacted with an alcohol in presence of a catalyst to produce methyl esters. Glycerol was produced as a byproduct of transesterification reaction.

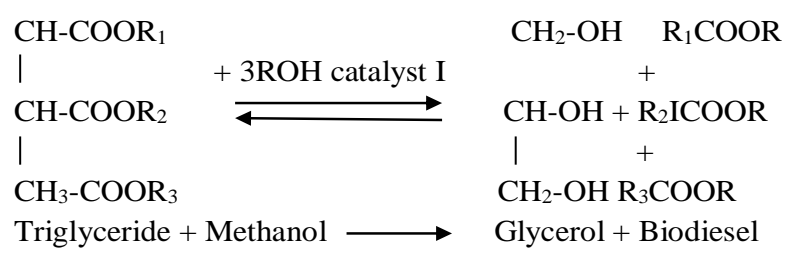

Where, $\mathrm{R}_{1}, \mathrm{R}_{2}$, and $\mathrm{R}_{3}$ are long chain hydrocarbons.

The mixture was stirred continuously and then allowed to settle under gravity in a separating funnel. Two distinct layers form after gravity settling for $24 \mathrm{~h}$. The upper layer was of ester and lower layer was of glycerol. The lower layer was separated out. The separated ester was mixed with some warm water (around $10 \%$ volume of ester) to remove the catalyst present in ester and allowed to settle under gravity for another $24 \mathrm{~h}$. The catalyst got dissolved in water, which was separated and removed the moisture. The methyl ester was then blended with mineral diesel in various concentrations for preparing biodiesel blends to be used in CI engine for conducting various engine tests (Fangrui and Hanna, 1999; and Deepak et al., 2007).

\section{Experimental Setup}

The Present study was carried out to investigate the performance and emission characteristics of Jatropha and Pongamia biodiesels and their blends in a stationary single cylinder diesel engine and to compare it with diesel fuel. Technical specifications of the engine are given in Table 1. The engine was coupled to a rope brake dynamometer. The major pollutants in the exhaust of a diesel engine are smoke.

\section{Engine testing}

Engine testing with diesel, Pongamia, Jatropha biodiesels and biodiesel blends were carried out to test the engine performance with respect to suitability of fuel. The test was carried out by using water cooled diesel engine of $5 \mathrm{BHP}$ $(3.7 \mathrm{~kW})$ (Rocket Engineering Corporation Pvt. Ltd., Shiroli, Kolhapur, Plate 1). The engine was operated on diesel first and then on methyl esters of Jatropha and Pongamia and their blends. The different fuel blends and mineral diesel were subjected to performance and emission tests on the engine. The performance data were then analyzed from the graphs. During the testing continuous water was supplied to cool the engine. The engine was loaded with four load conditions including, no-load, $25 \%$ load, $50 \%$ load, and $75 \%$ (Fig. 1). Under no load and $25 \%$ load $(3.22 \mathrm{~kg})$ conditions, cooling water level was maintained at the rate of $1.5 \mathrm{~L} / \mathrm{min}$ and for 50 $\%$ load $(6.45 \mathrm{~kg})$ and $75 \%$ load $(9.67 \mathrm{~kg})$ it was maintained at $3 \mathrm{~L} / \mathrm{min}$. Initially the engine was run with diesel fuel and then biodiesels 
and their blends for no load and load conditions. At each no load and load conditions ( $25 \%, 50 \%$, and $75 \%$ loads), time required to consume $50 \mathrm{cc}$ of fuel was noted down. Cooling water head was maintained at desirable level throughout the engine run. By using tachometer engine rpm was measured and various temperatures were noted down. Using gas analyzer (Kane International Ltd., Swallow fields, Wewyn Garden City, U.K.) $\mathrm{CO}(\mathrm{ppm}), \mathrm{CO}_{2}(\%), \mathrm{NO}_{2}(\mathrm{ppm})$ and $\mathrm{O}_{2}(\%)$ were measured from exhaust gas.

\section{Results and Discussion}

The experimental investigation was carried out for different blends of Pongamia and Jatropha methyl esters (biodiesel) and the performance was evaluated and compared with diesel.

The effect of engine load on brake power (PB) is shown in Figure 2. It can be clearly seen that the increase in engine loading increases the brake power linearly for all types of fuels and their blends under study. The rate of increase in BP was $200 \%$ when the engine load was increased from $25 \%$ to $50 \%$ or from $50 \%$ to $75 \%$. The behavior of biodiesels and their blends were exactly same and the responses were overlapping as that of diesel for generating the break power.

The performance of biodiesels and their blends were analyzed for brake specific fuel consumption (BSFC) at three engine loads
(Fig. 3). As the load increases brake specific fuel consumption decreases. Brake specific fuel consumption for biodiesel and its blends is higher than that of diesel because of lower calorific value. Jatropha biodiesel is having highest brake specific fuel consumption among all the test samples. Then the curves obtained in the form of inverse exponential curve.

Carbon monoxide (CO) emission (ppm) was slightly less for diesel when compared with biodiesel and their blends. The curves of different fuels are interpolating at some loads. The blend 2:1 has higher carbon monoxide emission among all the test samples (Fig. 4).

When we draw a graph of engine load vs carbon dioxide (\%) it gives linear curves. As the load increases $\mathrm{CO}_{2} \%$ increases. The value of $\mathrm{CO}_{2}$ for biodiesels and their blends are nearly equal to diesel $\mathrm{CO}_{2}$ value.

Then blend 2:1 has highest $\mathrm{CO}_{2} \%$ emission among all (Fig. 5). As the engine load increases $\mathrm{NO}_{2}$ (ppm) emission increases. Biodiesels and their blends having less $\mathrm{NO}_{2}$ than diesel and blend 1:1 have less $\mathrm{NO}_{2}$ among all the test samples. The curves obtained in positive exponential form (Fig. 6).

Based on the experimental results obtained while operating single cylinder diesel engine fuelled with biodiesel from Pongamia, Jatropha and their blends, the following conclusions were drawn.

Table.1 Engine specifications

\begin{tabular}{|l|l|}
\hline Type & Kirloskar \\
\hline Cylinder & Single \\
\hline Bore \& Stroke & $80 \times 110 \mathrm{~mm}$ \\
\hline Compression ratio & $16.5: 1$ \\
\hline Rated power & $3.7 \mathrm{~kW}$ at $1500 \mathrm{rpm}$ \\
\hline Injector opening pressure & $210 \mathrm{~B}$ \\
\hline
\end{tabular}


Plate.1 Experimental test rig for engine performance

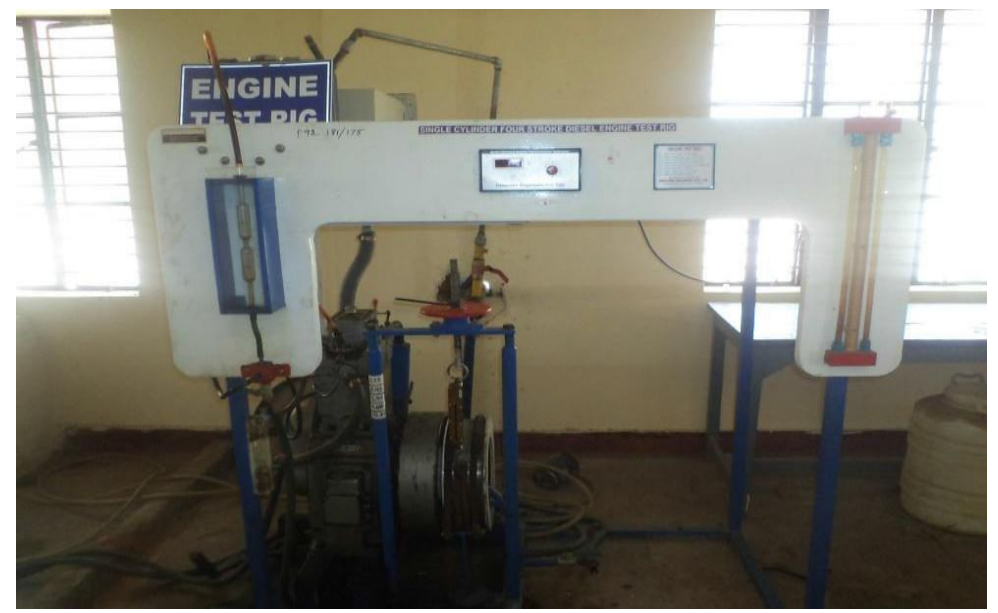

Fig.1 Experimental setup

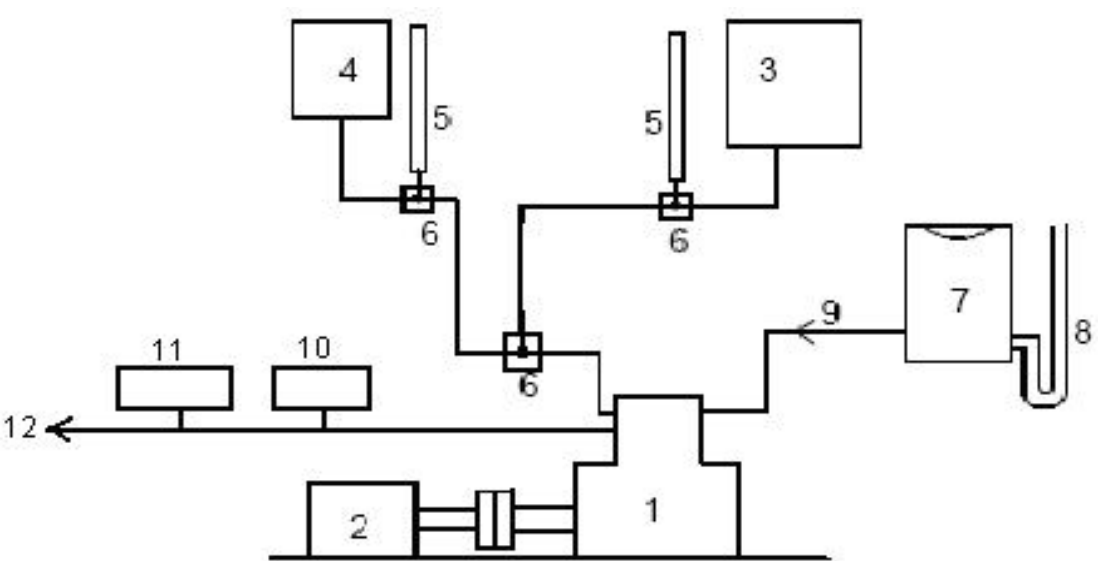

1) Engine 2) Dynamometer 3) Fuel Tank (Bio-diesel) 4) Diesel Tank 5) Burettes 6) Three way valve 7) Airbox 8) Manometer 9) Air flow direction 10) Exhaust Analyzer (CO (ppm), $\mathrm{CO}_{2}(\%), \mathrm{NO}_{2}(\mathrm{ppm})$ and $\mathrm{O}_{2}(\%)$ ) 11) Smoke meter 12) Exhaustflow

Fig.2 Effect of engine load on brake power using PB, JB and their blends

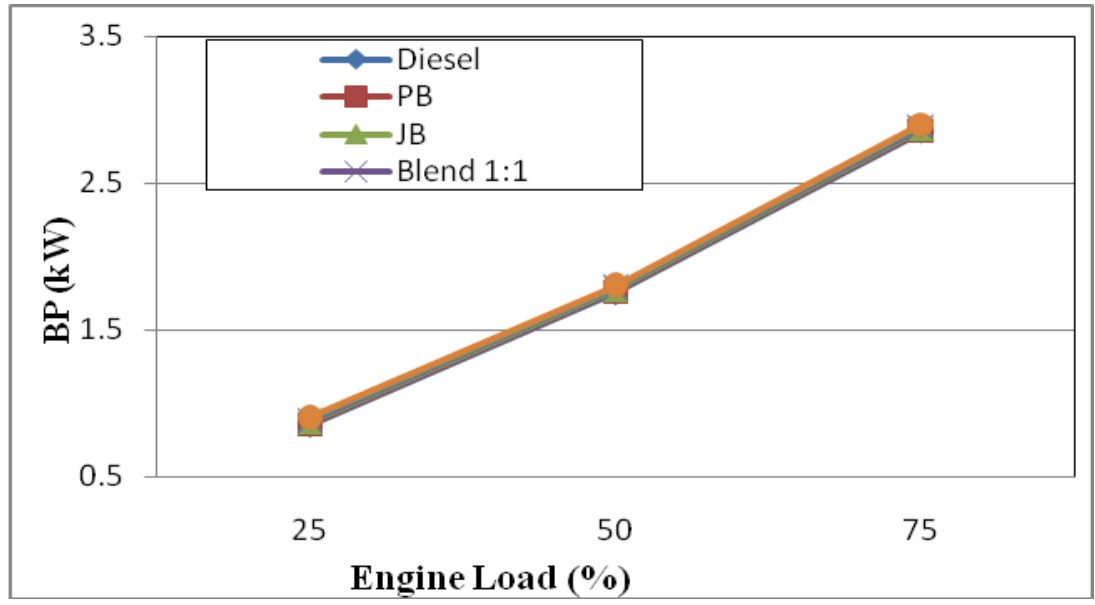


Fig.3 Effect of engine load on BSFC using PB, JB and their blends

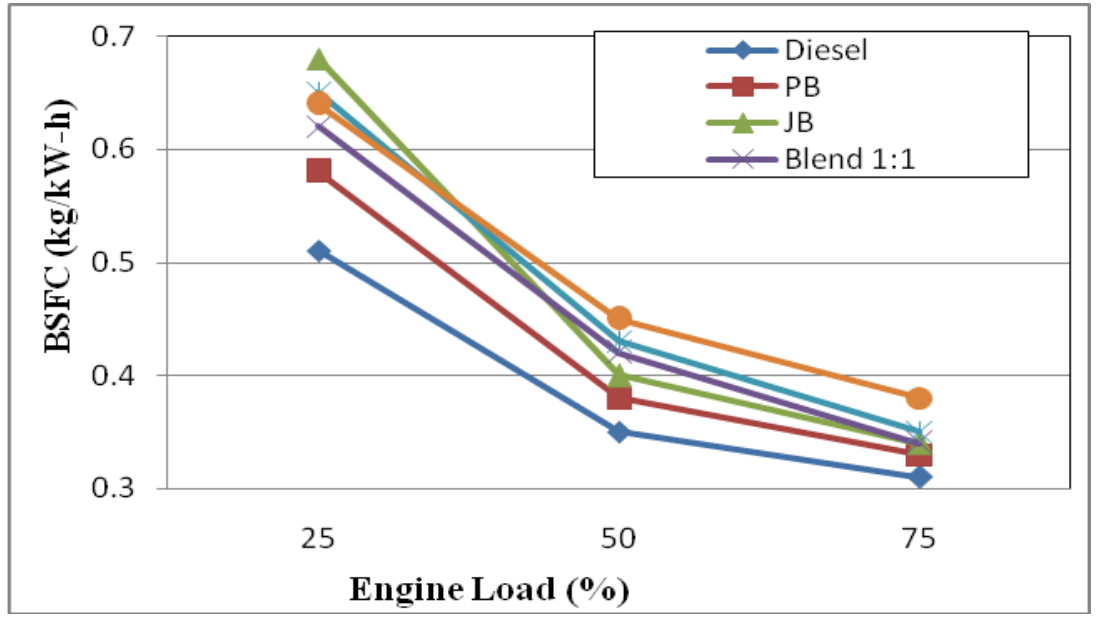

Fig.4 Effect of engine load on CO emission using PB, JB and their blends

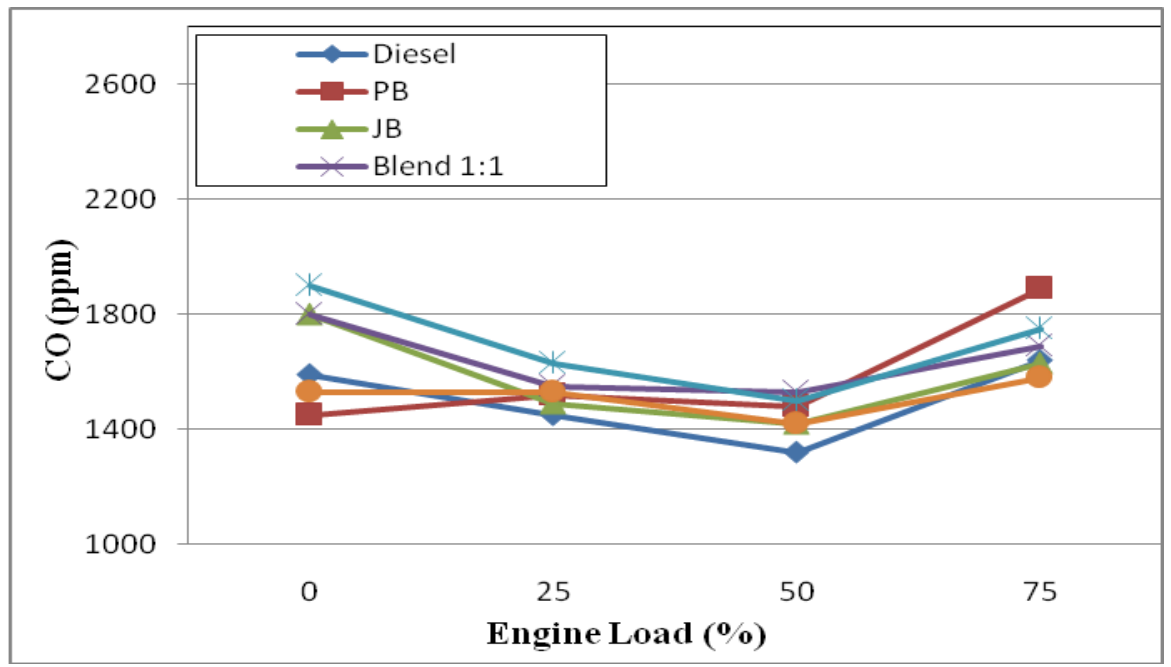

Fig.5 Effect of engine load on $\mathrm{CO}_{2}$ emission using PB, JB and their blends

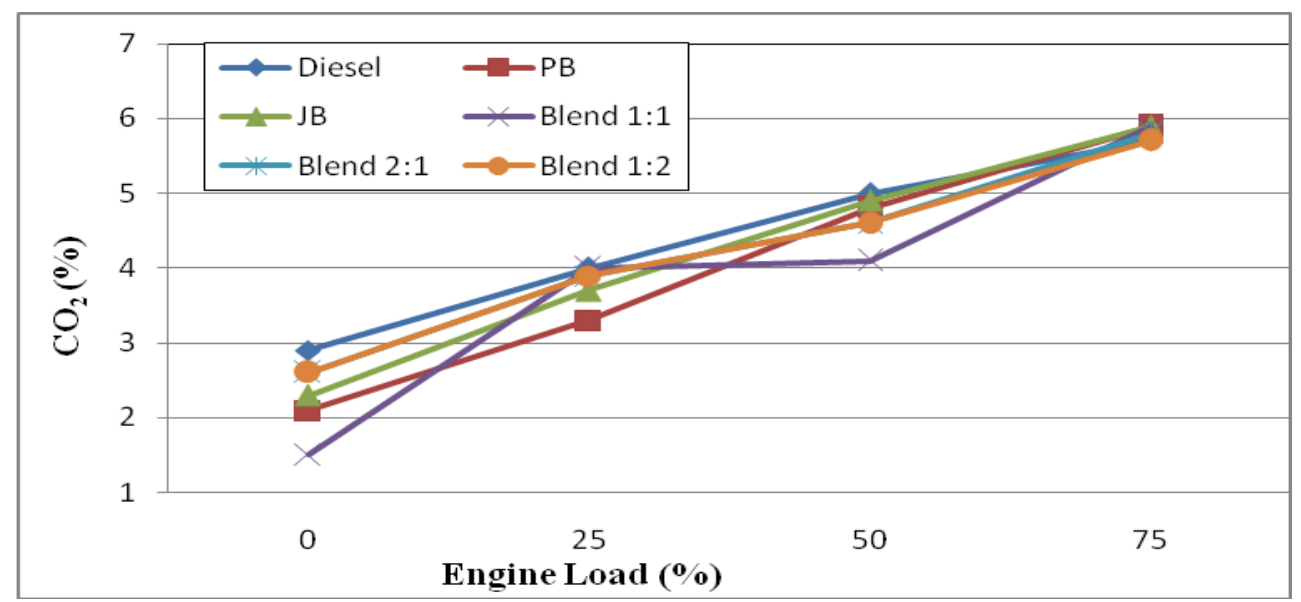


Fig.6 Effect of engine load on $\mathrm{NO}_{2}$ emission using $\mathrm{PB}, \mathrm{JB}$ and their blends

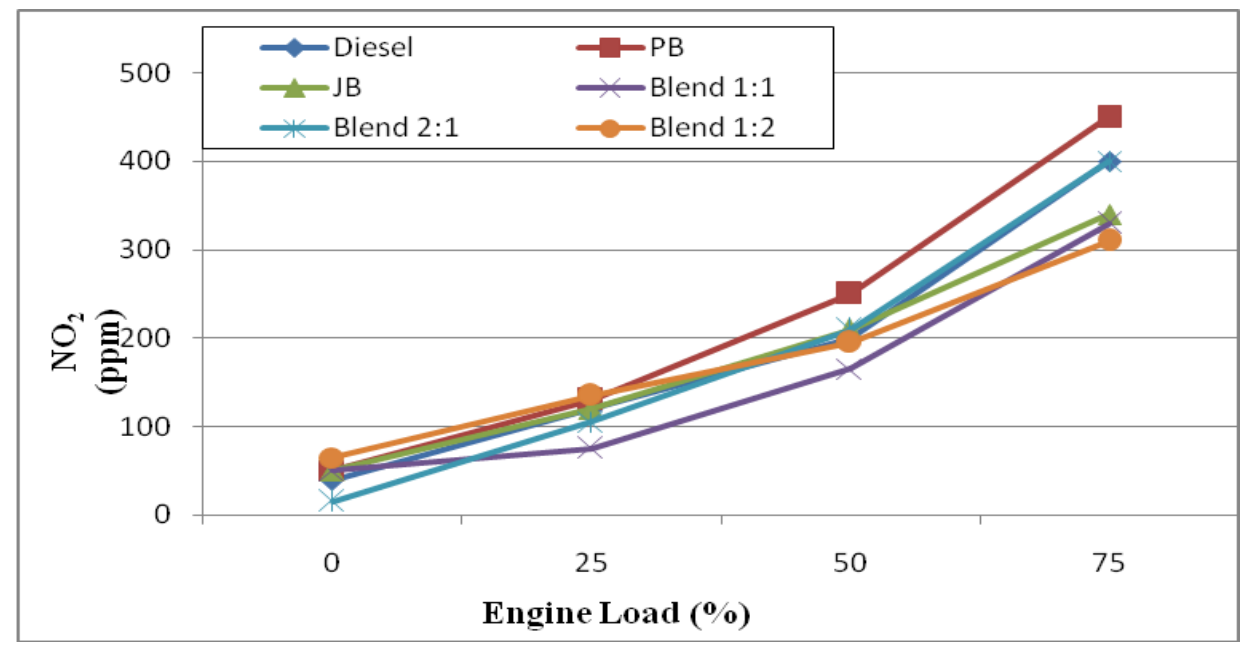

Pongamia and Jatropha based biodiesels can be directly used in diesel engines without any engine modifications.

Properties of different blends of biodiesel were very close to the diesel and were given good results.

It is not advisable to use blend $2: 1$ in $\mathrm{CI}$ engines.

$\mathrm{CO}$ emission at different loads was found to be higher for blend 2:1 biodiesel, compared to diesels and biodiesels and their blends.

$\mathrm{NO}_{2}$ emissions for diesel were found higher than biodiesel. Among the fuels $\mathrm{NO}_{2}$ emissions with Pongamia is noticed to be the lowest.

Good mixture formation and lower smoke emission are the key factors for good CI engine performance. These factors are highly influenced by viscosity, density, and volatility of the fuel. For Biodiesels, these factors are mainly decided by the effectiveness of the transesterification process. With properties close to diesel fuel, Biodiesel from Jatropha, Pongamia and their blends can provide a useful substitute for diesel thereby promoting our economy.

\section{References}

Agarwal D., L. Kumar, A.K. Agarwal, (2007). Performance Evaluation of a Vegetable oil fuelled CI Engine. Renewable Energy.

Barnwal B.K., M.P. Sharma, (2005). Prospects of biodiesel production from vegetable oils India, Renewable and Sustainable Energy Reviews, Vol. 9, 363-378.

Deepak Agarwal, Lokesh Kumar and Avinash Kumar Agarwal (2007), Performance Evaluation of a Vegetable Oil Fuelled CI Engine, Renewable Energy.

Fangrui, M. A and Hanna, M. A, (1999), Biodiesel Production a Review, Bio Source Technology, pp. 1-15.

\section{How to cite this article:}

Manasa, M., Shreekantgouda, Nagaraj Bake and Devanand Maski. 2018. Performance and Emission Analysis of Pongamia and Jatropha Biodiesels in a C.I. Engine. Int.J.Curr.Microbiol.App.Sci. 7(10): 2020-2025. doi: https://doi.org/10.20546/ijcmas.2018.710.233 